NURDINI FATHIRAINI

POLITIK LUAR NEGERI CHINA TERHADAP ZIMBABWE

\title{
POLITIK LUAR NEGERI CHINA TERHADAP ZIMBABWE
}

\author{
Oleh: \\ Nurdiani Fathiraini ${ }^{1}$
}

\begin{abstract}
This article aimed to elaborate China's foreign policy towards Zimbabwe under Hu Jintao's leadership. Based on the "social construction"logic, it was a logical consequence influenced by intersubjective factors and also formed and defined based on the actor's social identity. In this case, historical power influenced a positive intersubjective and form an established structure of China "amity" towards Zimbabwe. It can be understood how China perceived Zimbabwe as a "friend". Besides, China's identity transformation as a "peaceful rise" country, defined the interest formation towards economic and development cooperation manifested through strengthening cooperation in the ChinaZimbabwe Strategic Partnership's scheme. Thus, Hu Jintaos foreign policy towards Zimbabwe was not only determined by the material dimension, but strongly determined by the ideational dimension where China under Hu Jintao's leadership was strived to represent of a "peaceful rise" identity that cannot be separated from the values of "friendship, peace, cooperation, and development.
\end{abstract}

Keywords: Chinese Foreign Policy, Historical Power, Identity Transformation

\section{PENDAHULUAN}

Fenomena menarik di benua Afrika memasuki abad ke-21 diwarnai dengan kehadiran the emerging actors, yakni negara-negara Asia Timur yang semakin intens dan terlihat giat beraspirasi dalam rivalitas. China, Jepang, India, dan Korea Selatan, merupakan negara-negara yang dikenal memiliki pengaruh besar di Asia, semakin proaktif melakukan persuasi dan menjadi mitra utama berpengaruh di Afrika. Instrumen strategis terutama dalam hubungan perdagangan dinamis, investasi, dan inisiatif baru untuk bantuan pembangunan (developmental aid) kian memperkuat kehadiran China di Afrika.
Di bawah kepemimpinan $\mathrm{Hu}$ Jintao, China menunjukkan pendekatan terhadap Zimbabwe dengan mengambil langkahlangkah asertif untuk mendorong hubungan ke level yang lebih tinggi. China proaktif menjadi mitra dagang, investor, dan sebagai donor utama pembangunan di Zimbabwe. Diaspora China semakin terekspos publik internasional dengan terealisasinya sejumlah pembangunan infrastruktur, transportasi, pembangkit listrik, telekomunikasi, perumahan dan mega proyek lainnya di Zimbabwe. Dari pendekatan kontemporer China terhadap Zimbabwe ini, turut mengemuka adanya perkembangan berkesinambungan kedua

${ }^{1}$ Nurdiani Fathiraini adalah dosen di Departemen Pendidikan Sejarah, FPIPS, UPI. Penulis dapat dihubungi di email :fathiraini@upi.edu 
entitas melalui penguatan kerjasama dalam framework Strategic Partnership dengan menginisiasi hubungan "win-win relationship".

Zimbabwe sendiri merupakan negara yang mendapatkan sanksi negara-negara Barat, karena pemerintahan Zimbabwe African National Union - Patriotic Front (ZANU-PF) pimpinan Presiden Robert Mugabe dinilai telah melakukan pelanggaran demokrasi dan Hak Asasi Manusia (HAM). Inggris dan Amerika Serikat bahkan memimpin dalam mendorong masyarakat internasional untuk mengisolasi Zimbabwe dengan menjatuhkan sanksi. Uni Eropa pun turut menjatuhkan sanksi terhadap Zimbabwe pada tanggal 18 Februari 2002, dan kembali memberlakukan sanksi pada tahun 2013. Rekomendasi diberlakukannya penundaan terhadap keikutsertaan Zimbabwe ke dalam organisasi-organisasi internasional besar, seperti PBB, IMF, Bank Dunia serta Persemakmuran turut mengemuka. Disahkannya Zimbabwe Democracy and Economic Recovery Act (ZIDERA) oleh Kongres AS yang ditujukan untuk mendorong reformasi ekonomi dan politik di Zimbabwe diindikasikan sebagai sinyalemen intervensi Amerika Serikat untuk menekan pemerintah Zimbabwe.

Namun kontras dengan negara Barat, China justru muncul sebagai aliansi internasional terdekat Zimbabwe. Setelah selama periode Structural Adjustment Programs (SAPs) pada tahun 1991 hingga 1996, peran China di Zimbabwe sangat terbatas. Di bawah kepemimpinan $\mathrm{Hu}$ Jintao, China bahkan telah menfasilitasi sejumlah skema unconditional aid sebagai bagian dari framework Strategic Partnership menggantikan International
Monetary Fund (IMF) dan World Bank. Pendekatan China terhadap Zimbabwe sebagai "mitra pilihan" ini turut memunculkan pandangan berbeda khususnya dari negara Barat.

Beberapa analisis mengasumsikan bahwa pendekatan China terhadap Zimbabwe adalah murni hubungan ekonomi, didorong oleh insentif material, terutama oleh kebutuhan untuk bahan baku. Konsekuensi pertumbuhan pesat ekonomi China serta merta mendorong permintaan untuk bahan baku kritis yang banyak bersumber di Zimbabwe dan di sisi lain China tengah bersaing untuk potensi pasar yang besar di Zimbabwe. Relevansi asumsi-asumsi pada dimensi material tersebut tidak dapat dikesampingkan, namun tidak dapat diabaikan juga kekuatan dimensi ideasional turut mendorong perilaku negara.

Penulis membangun konsep-konsep utama yang akan digunakan untuk menjawab pertanyaan tulisan. Pengaturan konsep-konsep sebagai kerangka konseptual menjadi penting, karena hal tersebut mejadi dasar dimana bagian analisis akan dikembangkan. Adapun kontribusi konsep untuk mendapatkan asumsi mumpuni selama proses tulisan ini adalah dengan menggunakan perspektif konstruktivis.

Perspektif konstruktivis penulis gunakan untuk menganalisis politik luar negeri $\mathrm{Hu}$ Jintao terhadap Zimbabwe. Pilihan pada perspektif ini tidak terlepas dari beberapa kontribusi pemikiran konstruktivisme yang penulis pandang dapat membantu memberikan pemahaman politik luar negeri Hu Jintao, khususnya terletak pada ide untuk melihat perilaku negara melaluipendekatanyanglebih sosial 
atau intrepretivist. Oleh karena, untuk memahami interaksi negara kita tidak bisa hanya mendeskripsikannya dalam cara menjelaskan fenomena fisik namun juga membutuhkan berbagai jenis pemahaman interpretatif. Perilaku negara dalam sistem internasional tidak dapat dikalkulasikan hanya berdasarkan kekuatan material, tetapi merupakan hubungan "konstruksi sosial” yang mendefiniskan interaksi para aktor. Pada kasus politik luar negeri $\mathrm{Hu}$ Jintao terhadap Zimbabwe ini khususnya dibentuk oleh pemahaman intersubjektif dan identitas negara.

Tulisan ini bertitik tolak dari pemikiran Alexander Wendtyang menjelaskan bahwa, "premis kunci dari teori sosial idealis adalah bahwa perilaku negara terhadap objek-objek, termasuk aktor-aktor lainnya, berdasarkan meanings yang dimiliki objek-objek tersebut terhadap mereka" (1999, hlm. 140). Untuk memahami meanings dari perilaku negara, maka perlu ditempatkan dalam konteks intersubjektif atau konteks sosial intersubjektif. Tiaptiap perilaku negara, baik itu melakukan perang, menjalin hubungan baik, memutuskan hubungan, dan bahkan tidak melakukan hubungan dengan negara lain sekalipun didasarkan pada meanings. Meanings tersebut dapat dikonstruksi dari kombinasi ide-ide sejarah spesifik, normanorma, dan keyakinan yang spesifik dan kompleks. Senada dengan Wendt, Barnett memiliki argumen yang menyatakan, "reality does not exist 'out there' to be discovered but depends on construct and give meaning to reality" (2004, hlm. 259). Pemahaman atau keyakinan intersubjektif (sebagai bagian dari elemen ideasional konstruktivis) yang dimiliki decision maker memiliki efek konstitutif dan pada gilirannya memberikan orientasi lebih luas pada perilaku dan kebijakan. Dengan demikian tindakan negara ditentukan oleh struktur sosial dan bukan oleh struktur material

Lebih lanjut Wendt menguraikan konsepsi mengenai struktur sosial yang terdiri dari tiga elemen, yaitu: intersubjektivitas (shared knowledge), sumber daya material (materialresources), dan praktek-praktek (practices) atau wacana (1995, hlm. 73). Pertama, struktur sosial didefinisikan sebagai bagian dari intersubjektivitas pemahaman bersama (shared understanding, ekspektasi, atau pengetahuan). Faktor-faktor tersebut memiliki efek konstitutif terhadap aktor dalam situasi dan "nature" dari hubungan (sosial) mereka, apakah kooperatif atau konfliktual. Kedua, struktur sosial meliputi sumber daya material. Sumber daya material yang dimaksud adalah agar sumber daya itu memberikan pengaruh bagi tindakan negara, maka diperlukan pemaknaan. Konstruktivis berpendapat bahwa sumber daya material hanya memperoleh makna untuk tindakan manusia melalui struktur pengetahuan bersama (shared knowledge) dimana mereka melekat. Ketiga, struktur sosial ada, bukan di pikiran para aktor maupun dalam kapabilitas material, tetapi dalam praktekpraktek. Struktur sosial hanya ada dalam proses. Dengan kata lain praktek atau wacana dimaknai sebagai proses definisi atau redefinisi struktur sosial itu, yang berarti perilaku aktor akan berimplikasi pada penguatan atau pelemahan struktur sosial.

Lebihlanjuttulisaniniakanmengadopsi varian konstruktivis Alexander Wendt, dengan fokus utama identitas. Dengan asumsi, memahami identitas negara 
adalah penting terutama untuk memahami interaksinya dengan negara lain. Wendt memberikan penjelasan yang memberikan ruang bagi eksistensi dan peran agen dalam pembentukan identitas negara. Hal tersebut diaplikasikan Wendt di dalam melihat proses transformasi identitas dan kepentingan yang terjadi melalui, "the intentional efforts to transform egoistic identities into collective identities" yakni menggarisbawahi pada keinginan dan usaha kuat negara untuk merubah struktur identitasnya (Wendt, 1995, hlm. 133). Varian Wendt ini dikenal juga sebagai konstruktivis sistemik, yang memandang penting struktur internasional sebagai determinan dalam pembentukan identitas negara. Meskipun Wendt memberikan ruang penjelasan bagi peran domestik (agen) di dalam proses perubahan identitas suatu negara, namun proporsinya sangat kecil. Wendt tetap menekankan pada peran struktur sebagai faktor yang paling signifikan di dalam pembentukan identitas negara.

Untuk mengetahui persis bagaimana identitas negara mempengaruhi konstruksi kepentingannya vis a vis negara lain, membutuhkan konteks sosial yang mana identitas negara ini dikonstruksikan. Hal ini berarti elaborasi tidak hanya pada bagaimana identitas negara diproduksi dalam interaksinya dengan negaranegara lain, namun juga bagaimana identitas tersebut diproduksi melalui interaksi dengan masyarakatnya sendiri dan identitas-identitas dan wacana yang membangun masyarakat tersebut (Jackson \& Sorensen, 2007, hlm. 174-175).

Identitas negara ini direpresentasikan melalui decision-makers. Identitas kunci dari decision-makers dapat diketahui melalui sumber-sumber tekstual. Meskipun konstruktivis memiliki perdebatan mengenai signifikansi antara lingkungan domestik dan internasional, yang lebih penting adalah masingmasing varian menekankan pada kultur dan identitas yang direpresentasikan dalam norma-norma sosial, aturan, dan pemahaman-pemahaman. Esensi utama dari analisis konstruktivis adalah dunia sosial dan politik merupakan shared beliefs dibandingkan entitas fisik. Dengan demikian, konstruktivisme mengadopsi pendekatan yang mendalami sejumlah aspek paradigmatik yang kerap terabaikan dalam teori-teori berbasis kekuasaan dan kepentingan. Kritik konstruktivis pada khususnya ditujukan pada kepentingan dan identitas yang bersifat eksogen dari agen dan interaksi-interaksi yang telah ada sebelumnya (pre-exist interactions).

\section{HASIL DAN PEMBAHASAN}

Politik luar negeri Hu Jintao terhadap Zimbabwe merupakan "konstruksi sosial" yang dapat dipahami melalui konteks struktur sosial yang lebih luas. khususnya menggarisbawahi conscious construction terhadap kesejarahan dan identitas sebagai inti dari politik luar negeri adalah subjeksubjek yang dikonstruksikan secara sosial oleh negara. Sesuai asumsi yang dibangun melalui pendekatan konstruktivis adalah bagaimana dimensi-dimensi ideasional ini secara lebih spesifik mempengaruhi politik luar negeri Hu Jintao terhadap Zimbabwe.

\section{Konstruksi Kesejarahan}

Mengacu pada varian persepektif konstruktivis Alexander Wendt dimana, "premis kunci dari teori sosial idealis adalah bahwa perilaku negara terhadap 
objek-objek, termasuk aktor-aktor lainnya, berdasarkan makna yang dimiliki objekobjek tersebut terhadap mereka" (1999, hlm. 140). Untuk memahami makna dari perilaku negara, maka perlu ditempatkan dalam konteks sosial intersubjektif. Tiaptiap perilaku negara, baik itu melakukan perang, menjalin hubungan baik, memutuskan hubungan, dan bahkan tidak melakukan hubungan dengan negara lain sekalipun didasarkan pada makna. Makna dapat dikonstruksi dari perpaduan ideide sejarah, norma-norma, keyakinankeyakinan yang spesifik dan kompleks. Perspektif konstruktivis memandang kekuatan sejarah sebagai faktor yang memungkinkan agen negara untuk mengkonstruksi dan menetapkan makna.

Berdasarkan serangkaian fase-fase interaksi signifikan, elit China khususnya memandang negaranya telah memiliki sebuahhubungankesejarahanyangpanjang (long standing historical relationship) dengan Zimbabwe. Hubungan diplomatik China dan Zimbabwe memasuki periode kepemimpinan $\mathrm{Hu}$ Jintao telah berjalan lebih dari 30 tahun. Dalam beberapa pernyataan resmi pemerintah China kepada publik diserukan bahwa hubungan kedua entitas merupakan salah satu yang telah berjalan lama, dimana "relations between China and Zimbabwe started in the days of the liberation struggle in the African country when China aided the liberation fighters in various ways" (People's Daily, 2006) dan "The People's Republic of China cherish the traditional friendship with Zimbabwe, which dates back to the pre-independence era..." (People's Daily, 2006). Fase-fase tersebut membentuk intersubjektif positif elit China yang kemudian mempengaruhi elit China dalam menetapkan makna Zimbabwe sebagai "teman".

Dengan kata lain perilaku China ini tidak lepas dari makna yang dimiliki terhadap objek atau subjek lain. Faktor intersubjektif negara dibangun dari kekuatan kesejarahan pada fase-fase signifikan interaksi kedua entitas yaitu, interaksi China dan gerakan pembebasan nasionalis Zimbabwe yang tidak terlepas dari agenda revolusioner dan stance antihegemoni China, dan interaksi paska Tiananmen dengan dukungan Zimbabwe yang mengemuka pada prinsip noninterferensi dan kedaulatan.

Pada fase interaksi China dan gerakan pembebasan nasionalis Zimbabwe, hubungan China dan gerakan-gerakan pembebasan nasionalis Zimbabwe lebih disesuaikan pada kebutuhan-kebutuhan China dibandingkan dengan organisasiorganisasi pembebasan itu sendiri (Taylor, 2006, hlm. 106). Dukungan China terhadap gerakan pembebasan dipandang sebagai metode efektif untuk melakukan propaganda anti-Soviet di negaranegara Afrika. George T. Yu menjelaskan bahwa dukungan China untuk gerakan pembebasan di Afrika terbukti memberi manfaat, dan model komunis China mengobarkan "people's war" terbukti sukses khususnya di kawasan Afrika bagian selatan (Youde, 2007, hlm. 7).

Negara-negara ini menerima pasokan senjata dan pasokan material lainnya untuk dipergunakan dalam perjuangan bersenjata. Selain material, beberapa negara didukung dengan pelatihan militer untuk perang gerilya melawan pemerintahan imperialis. Melalui dukungannya tersebut, China dengan mudah dapat mendiskreditkan Uni 
Soviet sebagai kekuatan revolusioner, mengidentifikasikannya dengan imperialisme Amerika Serikat, dan pada akhirnya memperkuat China sebagai pemimpin revolusi sosialis dunia.

Keterlibatan China di Zimbabwe disinyalir kuat telah memberikan pengaruh dalam merubah taktik dan ideologi dari organisasi pembebasan ZANU. Dalam hal ini ZANU mendapat bantuan militer dan strategis China dalam perjuangan kemerdekaan. China turut serta memfasilitasi pelatihan gerilyawan dari sayap militer ZANU yaitu Zimbabwe African National Liberation Army (ZANLA). Di bawah pola didik China, taktik militer ZANLA mengalami transformasi mendasar dari taktik militer konvensional dengan mengadopsi model Maois yang syarat dengan mobilisasi massa untuk melakukan revisionalisasi penduduk kulit hitam Rhodesia.

Pelatihan politik dan militer China untuk ZANLA adalah sebagai bagian dari agenda revolusioner, serta stance oposisi China terhadap superpower (khususnya Uni Soviet). Dihadapkan pada sejumlah kekhawatiran akan meningkatnya power dan pengaruh "new Tsars" sebagai pretensi aspirasi-aspirasi hegemonik Soviet, turut mendesak China untuk mengambil langkah antisipatif dengan memberikan dukungan pada perjuangan-perjuangan negara Afrika. Dimana tercatat delapan puluh peperangan di Zimbabwe tidak dapat dilepaskan dari intervensi China.

Meningkatnya sikap bermusuhan China terhadap Soviet menjadikan ZANU target utama dukungan China. Kehadiran ZANU sebagai organisasi baru yang "murni" dari pengaruh Soviet dipandang China sangat tepat, terutama oleh karena perpecahan yang terjadi antara China dan Soviet. ZANU dalam konteks ini berpotensi sebagai medium penyebaran, dimana posisi anti-Soviet China di Afrika dapat tercapai (Taylor, 2006, hlm. 107). Sejak saat itu, ZANU menjadi mata rantai dan sebagai aliansi utama China di Afrika bagian selatan.

Menjadi catatan penting bahwa kepemimpinan ZANU baik itu Robert Mugabe dan beberapa anggota pemerintahan ZANU-PF saat ini, adalah aktor-aktoryangmengambilalih kekuasaan pada saat kemerdekaan Zimbabwe tahun 1980. Zimbabwe tidak hanya mengadopsi prinsip-prinsip dan taktik China ke dalam sistem pemerintahan, Mugabe bahkan mengklaim dirinya sebagai "a MarxistLeninist of Maoist though." Mugabe menunjukkan komitmennya untuk sosialisme dan turut serta mengobarkan "people's war" (Youde, 2007, hlm. 8). Mugabe bahkan mengirimkan sejumlah besar pasukan untuk mendapatkan pelatihan militer di China. Dengan pelatihan militer yang diberikan China untuk Zimbabwe, direspon positif dengan janji Mugabe untuk mempertahankan hubungan yang lebih kuat dengan China. Hal tersebut dibuktikan terutama ketika Zimbabwe telah berhasil menggulingkan pemerintah minoritas kulit putih Ian Smith.

Pemerintahan Zimbabwe dan interaksi ekonomi antara kedua negara masih kental dipengaruhi elemen-elemen China. Hal ini terutama karena sosialisasi China selama bertahun-tahun sejak awal keterlibatan dengan sebagian besar pemimpin ZANUPFsaatinimasihmengendalikankekuasaan di Zimbabwe. Pada 18 April 1980, partai ZANU berhasil mengambil kendali 
pemerintahan dengan mengukuhkan Mugabe sebagai Perdana Menteri setelah secara mutlak memenangkan pemilu multiras pertama di Zimbabwe. Mengiringi perubahan konstitusi di Zimbawe pada tahun 1987, Mugabe diangkat menjadi Presiden dan mampu bertahan selama lebih dari dua dekade. Pada tahun 1987 ZANU dan ZAPU menjadi satu, kemudian membentuk ZANU-PF (Patriotic Front). Hal tersebut dipandang sebagai cikal bakal langkah menuju negara satu partai yang diadvokasi Mugabe. Paska terbentuknya pemerintahan Zimbabwe yang baru, China pun meresmikan hubungan diplomatiknya.

Fase interaksi signifikan China dan Zimbabwe berikutnya adalah paska Tiananmen dengan dukungan Zimbabwe yang mengemuka pada prinsip noninterferensi dan kedaulatan. Tindakan represif pemerintah Beijing kepada para demonstran pendukung pro-demokrasi di Lapangan Tiananmen menyebabkan konsekuensi signifikan dalam hubungan internasional China. China harus dihadapkan pada berbagai tekanan negaranegara Barat dan terisolasi dalam sistem internasional. Tindakan pemerintah China terhadap para demonstran kian memperburuk hubungan China dan Barat.

Kecaman-kecaman tersebut sertamerta melemahkan posisi China yang telah dinilai gagal dalam menegakkan prinsip-prinsip HAM internasional. Namun demikian, isolasi politik dan sanksi ekonomi yang diberlakukan oleh negara-negara Barat menyusul peristiwa Tiananmen menjadi titik balik China untuk "menemukan kembali" teman Afrika nya. China memandang kuat negara-negara Afrika ini sebagai "reserve pool of likeminded national elites upon whom China could count on for support" (Cornelissen \& Taylor, 2000, hlm. 618-619).

Dominasi numerik negara-negara Afrika memberi kesempatan China untuk mendapatkan suara pada Mahkamah Umum PBB, terutama mencegah organisasi-organisasi internasional memberlakukan resolusi sanksi atas China. China menggaris bawahi pentingnya prinsip non-inteferensi atas kedaulatan negara, dimana pandangan negara-negara Barat tentang HAM akan turut berpotensi mengancam pemerintah Afrika. Pemerintah China mengadvokasi para pemimpin Afrika untuk bergabung bersama China melawan hegemoni Amerika.

Zimbabwe pun cepat merespon retorika China dan membela peran pemerintah China pada peristiwa Tiananmen. Mugabe sendiri memandang wajar upaya pemerintah China melakukan langkahlangkah stabilisasi situasi domestik negaranya. Selama krisis berlangsung, pemerintahan Zimbabwe bahkan secara asertif menolak kampanye anti-China yang diproyeksikan oleh negara-negara Barat dan turut menentang pemberlakuan konsep Barat tentang Hak Asasi Manusia (HAM) dan demokrasi (Taylor, 2006, hlm. 121). Mugabe menilai isolasi politik Barat dipandang sebagai konspirasi lingkaran negara-negara Baratatas China. Pengenaan sanksi, khususnya karena pelanggaran terhadap konsep-konsep Barat untuk HAM dan demokrasi merupakan upaya Barat untuk mendestabilisasi dan menyabotase ekonomi China yang tengah berkembang. Meskipun peristiwa Tiananmen telah merusakcitrapemerintah China, namunhal tersebut tidak hanya semakin memperkuat hubungan China dengan Zimbabwe tetapi 
juga dengan negara-negara Dunia Ketiga lainnya. Dunia Ketiga berdiri tegas sebagai konstituen yang kuat bagi China untuk mempertahankan kedaulatan dan hak-hak bagi pemerintahan China.

Penjelasan di atas penting untuk dapat menjelaskan prinsip-prinsip hubungan kedua negara. Sejak awal, kedua entitas saling menghormati untuk menjalankan sistem pemerintahan masing-masing, seiring China menginternalisasi prinsipprinsip kedaulatan dan non-interferensi sebagai dasar dalam interaksi internasional (Cornelissen \& Taylor, 200o, hlm. 618). Sebagai konsekuensinya, China dan Zimbabwe telah memiliki pondasi kuat hubungan, sebagaimana keduanya terus mengarahkan bentuk dan ruang lingkup interaksi hingga saat ini. Kedua entitas sejalan untuk terus mendukung satu sama lain, bahkan ketika salah satu diantaranya harus dihadapkan dengan berbagai sorotan dan kecaman masyarakat internasional. Secara politis, hal tersebut menjadi imperatif bagi China untuk mempertegas posisinya dalam sistem internasional, tujuan ini menjadi pendorong utama dari keterlibatannya di Afrika, khususnya di Afrika bagian selatan (Taylor, 1997, hlm. 12).

\section{Transformasi Identitas}

Transformasi identitas China disebabkan oleh adanya intentional efforts to transform egoistic identities into collective identities (intentional efforts: transformasi dari corporate identity ke social identity). Dimana faktor-faktor pendorong transformasi identitas China merupakan resultansi dari penilaian agen tentang kondisi internal maupun eksternal (struktur internal dan struktur domestik).
Identitas "peaceful rise" (heping jueqi) adalah identitas sosial China pada era $\mathrm{Hu}$ Jintao. Identitas "peaceful rise" menggarisbawahi dan adanya hubungan antara self dan other sebagai identifikasi pada konklusi logis, yaitu China sebagai great power dan image-building as a responsible power (fuzeren de daguo). Dengan identitas sosial tersebut China memandang dan menerjemahkan dirinya sebagai negara yang damai dan merepresentasikan soft power.

Secara kongkrit China mengartikulasikan upaya-upaya yang mendorong harmoni dalam interaksi internasional melalui karakteristik kebijakan-kebijakan (ideal dan normatif) yang lebih kooperatif pada berbagai aspek dan menitikberatkan pada pembangunan bersama (common development) antar negara, serta berupaya mewujudkan interaksi yang lebih benign antara pembangunan negaranya dan perdamaian dunia, dibandingkan dengan mengejar kepentingan material. Hal tersebut mengarahkan pemerintah China mengadopsi pendekatan kebijakan mempertahanan stabilitas dari sistem internasional dimana China mengambil inisiatif aktif untuk mewujudkan lingkungan internasional yang damai dan menguntungkan. "Perdamaian dan harmoni” menjadi panduan dasar bagi kebijakan luar negeri. Intinya adalah membangun lingkungan internasional yang lebih stabil dan seimbang untuk keberlanjutan perkembangan dan pembangunan China.

Identitas "peaceful rise" China menjadi alasan utama untuk substansi definisi pengembangan kepentingan China pada kerjasama dan pada gilirannya politik 
luar negeri China terhadap Zimbabwe. Fakta esensialnya adalah bahwa aktor internasional memiliki agen yang membuat pilihan-pilihan dan menunjukkan perilaku yang disengaja dalam mentransformasi identitas "peaceful rise" China, dan pada gilirannya menghasilkan disposisi motivasi dan perilaku. Dengan identitasnya tersebut, perilaku dan tindakan China akan disesuaikan dengan keyakinan tentang siapa mereka, sesuai dengan identitasnya tersebut.

Menggarisbawahi bahwa suatu perubahan struktur identitas dan kepentingan selalu dipengaruhi dan ditentukan oleh upaya dan keinginan dari negara untuk melakukan perubahan yang menurut Wendt merupakan bentuk dari "personal determination choice". Dengan kata lain terjadinya perubahan dalam konteks ini merupakan hasil dari self-consciouss efforts untuk melakukan perubahan terhadap struktur identitas dan kepentingan. Bentuk perubahan itu akhirnya dapat dilihat sebagai suatu pilihan identitas baru yang menentukan peranan China dalam menangani isuisu pembangunan dan perkembangan negaranya. Perubahan peran China dapat dilihat dalam bentuk-bentuk kebijakan yang lebih pro-pembangunan dan kerjasama. Berdasarkan identitas "peaceful rise" elit negara memiliki preferensi untuk mengembangkan kepentingan pada kerjasama. Interaksi antara bagaimana aktor memandang identitas, membentuk kepentingannya, pada akhirnya menjadi determinan yang mempengaruhi politik luar negeri China.

"China today is a country in reform and opening-up and a rising power dedicated to peace" adalah isi penggalan pidato
Perdana Menteri China Wen Jiabao di Universitas Harvard pada bulan Desember tahun 2003. Pidato ini memberikan deskripsi dari konstruksi identitas "peaceful rise" China (zhongguo de jueqi) pada administrasi $\mathrm{Hu}$ Jintao. Identitas "peaceful rise" China menguraikan "the new way path" (xin daolu) dan arahan strategis untuk interaksi internasional China sebagai negara yang damai, dan tidak menjadi ancaman bagi keamanan negara manapun. Identitas "peaceful rise" China terutama memproyeksikan China sebagai kekuatan yang tengah bangkit (rising power) tanpa mendestabilisasi tatanan sistem internasional yang telah ada.

Identitas "peaceful rise" menekankan karakterisasi China sebagai negara yang bertanggung jawab, menekankan soft power dalam interaksi internasional, dengan premis bahwa hubungan baik dengan negara-negara lain akan meningkatkan kekuatan komprehensif nasional China. Esensi komitmen yang dibangun China dalam identitasnya adalah "to build an all-round well-off society internally and to maintain world peace and promote common development externally" (White Paper on Peaceful Development Road, 2005), dimana dengan reformasi, keterbukaan, dan kebangkitan negaranya, akan mendorong China berperan lebih aktif terutama untuk memberikan kontribusi signifikan dalam pembangunan, penciptaan kesejahteraan, dan menjaga stabilitas keamanan dengan negara-negara lainnya.

Dalam identitas "peaceful rise" elit China khususnya menggarisbawahi diferensiasi sosial negaranya dan rising powers terdahulu (yang secara historis 
memiliki kecenderungan bertransformasi menjadi hegemoni). Terutama kontestasi pada sejumlah rising powers yang kerap melakukan perampasan sumbersumber daya negara lain melalui invasi, penjajahan, ekspansi eksternal, dan agresi melalui perang berskala besar. Kontras dengan hal tersebut, stance China dalam konteks identitas "peaceful rise" nya adalah mengesampingkan kebijakan-kebijakan persaingan yang berpotensi menimbulkan konflik dan berusaha untuk menghindari konfrontasi internasional yang tidak perlu.

China mengklaim kebangkitan negaranya lebih didorong oleh modal, teknologi, dan sumber daya yang diperoleh melalui cara-cara damai (Zheng Bijian, 2005, hlm. 19-20). Demikian halnya perkembangan ekonomi serta pengaruh China secara internasional adalah sebagai bagian dari proses positif dan bukan sebagai ancaman untuk major powers dan negara-negara berkembang. Bertitik tolak dari pandangan tersebut, para pembuat kebijakan China memberikan poin penting dimana:

"the only choice for China under the current international situation is to rise peacefully, namely, to develop by taking advantage of the peaceful international environment, and at the same time to maintain world peace through its development” (Zheng Bijian, 2005).

Dengan demikian konsep identitas "peaceful rise" mendorong partisipasi positif China dalam perekonomian internasional. Partisipasi China dalam globalisasi ekonomi dan interaksi dengan negara-negara lain di pasar dunia adalah untuk merealisasikan win-win result. Partisipasi positif ini adalah sebagai bagian dari jalur pembangunan independen yang tetap dipertahankan China untuk membangun sosialisme melalui keterlibatan dan bukan melalui isolasi dari globalisasi ekonomi. Dan sebagai kesediaan China untuk menerima peluang berikut tantangan globalisasi ekonomi, China akan memainkan perannya sebagai responsible power.

Sebagai konsekuensi logis dari identitas "peaceful rise", China di bawah administrasi $\mathrm{Hu}$ Jintao melakukan diplomasi aktif dengan menitikberatkan pada konsep "peaceful development" (heping fazhan) sebagai negara yang tidak akan menjadi ancaman maupun menghalangi perkembangan negaranegara lainnya. Pada Desember 2005, China's State Council mempublikasikan "White Paper on Peaceful Development Road," dengan menekankan lima poin penting, yaitu:

1. Sebagai arahan yang tak dapat dielakkan lagi dari modernisasi China;

2. Memajukan perdamaian dan pembangunan dunia seiring dengan perkembangan negaranya;

3. Pembangunan hanya dengan mengandalkan kekuatan sendiri, yakni melalui reformasi, dan inovasi;

4. Secara bersama-sama melakukan upaya-upaya untuk saling memberi manfaaat (mutual benefit) dan pembangunan bersama (common development) dengan negara-negara lain;

5. Membangun harmonious world melalui perdamaian yang berkelanjutan dan kesejahteraan bersama (common prosperity) (White Paper on China's Development Road, 2005). 
Dokumen ini merupakan bentuk komitmen China pada peaceful development sebagai hal yang "tak terelakkan lagi dalam modernisasi China". Sebagai konsekuensi dari komitmen China tersebut, kemakmuran ekonomi masa depan China akan sangat tergantung pada upaya China menghindari konflik dengan kekuatan-kekuatan regional dan ekstraregional, dan memastikan keterbukaan sistem ekonomi internasional yang mana kompetisi ekonomi yang dinamis dan pesat (hyper-competitive economy) dapat terus menguntungkan.

Implementasi "peaceful rise" terhadap Zimbabwe. Identitas "peaceful rise" pada gilirannya menentukan interaksi China pada "nature" kooperatif melalui kerjasama. Identitas tersebut turut menjadi determinan dalam inisiasi China sebagai aktor yang menekankan pendekatan berfokus pada kerjasama ekonomi dan kerjasama pembangunan terhadap Zimbabwe yang diimplementasikan melalui penguatan kerjasama Strategic Partnership. Strategic Partnership mendorong kepada hubungan perdagangan dinamis, investasi, dan bantuan pembangunan (development assistance) yang ditujukan untuk membangun positive sum relations dan mutual benefit.

Kebudayaan yang tercipta dalam masyarakat tidak terlepas dari adanya interaksi atau aktifitas sesama anggota masyarakatnya. sejarah muncul dan perkembangan Angklung Gubrag.

\section{SIMPULAN}

Politik luar negeri Hu Jintao terhadap Zimbabwe merupakan "konstruksi sosial" yang dapat dipahami melalui konteks struktur sosial yang lebih luas. Kekuatan kesejarahan pada fase-fase signifikan interaksi membentuk identifikasi positif China terhadap Zimbabwe, struktur mapan "amity" (dimana China memandang Zimbabwe sebagai "natural friend of China", aliansi untuk prinsipprinsip kedaulatan, non-interferensi, dan mendukung China sebagai "leading state" untuk menata pembangunan ekonomi global) dan membangun pemikiran elit politik untuk bergerak dalam framework possible action mengembangkan politik luar negeri terhadap Zimbabwe. Manifestasi politik luar negeri Hu Jintao melalui penguatan kerjasama dalam Strategic Partnership bukan merupakan konsep statis melainkan dapat dipahami sebagai structuring framework yang dibangun atau dikembangkan melalui praktek-praktek sosial dan yang mana adalah sebagai subjek pada perubahan sosial.

\section{DAFTAR PUSTAKA}

\section{Buku}

Barnett, M., \& Finnemore, M. (2004). Rules for the World: International Organizations in Global Politics. Ithaca: Cornell University Press.

Jackson, R., \& Sorensen, G. (2007). Introduction to International Relations: Theories and Approaches. Chapter 6: Social Constructivism. Oxford: Oxford University Press.

Taylor, I. (2006). China and Africa: Engagement and Compromise. London: Routledge.

Wendt, A. (1999). Social Theory of International Politics. Cambridge: Cambridge University Press. 


\section{Artikel Jurnal}

Cornelissen, S., \& Taylor, I. (2000). The Political Economy of China and Japan's relationship with Africa: A Comparative Perspective. The Pacific Review. Vol. 13, hlm. 615-633.

Taylor, I. (1997). China's Foreign Policy towards Southern Africa in the 'Socialist Modernisation' Period. East Asia Project. University of the Witwatersrand: Johannesburg.

Wendt, A. 1995. Constructing International Politics. International Security. Vol. 20, No. 1.

Youde, JR. 2007. Why Look East? Zimbabwean Foreign Policy and China. Africa Today. Vol. 53, No. 3, hlm. 3-19.

\section{Artikel Website}

"China pledges more aid to Zimbabwe". (2006). People's Daily [Data File]. Diperoleh dari http://english. peopledaily.com.cn/200602/24/ eng20060224_245487.htm

White Paper on Peaceful Development Road Published. (2005). China.org.cn. Diperoleh dari http://www.china.org. cn/english/2005/Dec/152669.htm

Bijian, Z. (Sept/ Oct 2005). China's "Peaceful Rise" to Great-Power Status. Foreign Affairs. Diperoleh dari https:// www.foreignaffairs.com/articles/ asia/2005-09-01/chinas-peaceful-risegreat-power-status 